\title{
FORMATION OF READINESS FOR DIALOGUE IN PROFESSIONAL ACTIVITY OF FUTURE MANAGERS OF FOREIGN ECONOMIC ACTIVITY
}

\section{ФОРМУВАННЯ ГОТОВНОСТІ МАЙБУТНІХ МЕНЕДЖЕРІВ ЗОВНІШНЬОЕКОНОМІЧНОЇ ДІЯЛЬНОСТІ ДО ДІАЛОГУ В ПРОФЕСІЙНІЙ СФЕРІ}

The processes of globalization, the strengthening of intercultural communication in the world community define new requirements for the training of future managers of foreign economic activity - officials whose duty is to manage the organization, its subdivision, conducting a certain direction of work in the conditions of increasing cooperation and competition in the economy and business. Practice shows that today in this sphere, there are stronger connections and communication between representatives of different cultures, both in direct communication and in electronic communication. Today the goals of the education of managers are aimed not only at the formation of knowledge and skills in the organization of the management process, but also on the development of communication skills, the ability to clearly state their own opinion, to substantiate conclusions about solving problems, to convey knowledge and ideas. In the light of such demands, the problem of forming readiness for professional activities on a dialogical basis among students-future managers of foreign economic activity becomes more important. The purpose of the article is to carry out an analysis of the theoretical and practical foundations of future managers' readiness for dialogue in the future professional activity and to determine the conditions for the successful implementation of this task by higher management education.

The article substantiates the place and role of dialogical communication in the professional activity of managers of foreign economic activity, the importance of forming readiness for dialogue in the student age; the analysis of the concepts of "dialogue", "interaction", "dialogic interaction" are considered; the conditions and advantages of dialogical communication are examined, the levels of dialogical interaction in the educational process are determined; The modern forms and methods of training managers as an important factor in achieving the necessary level of preparedness of future international managers for dialogue are revealed; considerable attention is paid to the requirements for the study of a foreign language an effective means of increasing the communicative abilities of students and their level of readiness for dialogic interaction.

Key words: manager, foreign economic activity, professional activity, dialogue, readiness for dialogue, dialogic interaction, pedagogical interaction, teaching methods.

Modern changes in society, the processes of globalization of the world economy, modernization of production, development of information and communication technologies make new demands for the training of managers, including of foreign economic activity. From the education system is expected not only the provision of knowledge and the formation of skills to organize the management process, but also the development of the creative abilities of students, the ability to communicate, the ability to communicate clearly and unequivocally their own conclusions, knowledge, problems, ideas. In the light of such demands, the problem of forming readiness for professional activities on a dialogical basis among students-future managers of foreign economic activity becomes more important. Its relevance is due to the growing role of such specialists in the development of the state, the expansion and intensification of international relations, new social relations, which at present are not always built only on the basis of economic interests.

(C) Ольга Ельбрехт, 2018 
Brief Literature Review. The problem of forming readiness for professional activities on a dialogical basis - multi-aspect, topical, draws attention of many researchers. Analysis of literary sources made it possible to identify the problems of communication and dialogue, which are explored by scientists. These are the problems of interaction (B.Vulfov, I. Zhbankova, V. Semenov and others), psychological aspects of dialogical interaction (G. Kovalyov, N. Kolomensky and others); humanization of communication through dialogue forms of interaction (M. Bakhtin and others); development of multiculturalism - an important means of achieving mutual understanding (M. Holovatyi and others); reflexive possibilities of dialogue in the formation and self-development of the individual (G. Suhobskaya and others); dialogical education (N. Schurkov and others); formation of readiness of students for dialogical learning (V. Morozov and others); organization of educational dialogue (I. Glazkova and others); formation of a culture of communication among future managers (V. Liventsova and others); paradigmatic principles of dialogical thinking (N. Grinchishin and others); culture of dialogue as an important component of the professional activity of a specialist (V. Berkov, L. Vygotsky and others); the organization of training on the model of "dialogue of cultures" (I. Bakhov and others); formation of a culture of professional communication of future specialists (S. Amelin and others). However, the analysis of the practice of managers of foreign economic activity reveals a number of contradictions, which requires the attention of scientists and practitioners to the formation of readiness for dialogue in professional activity among students during their studies at a higher education institution.

Aims and tasks. Purpose of the present publication is to carry out an analysis of the theoretical and practical foundations of the future managers' readiness for dialogue in their future professional activity and to determine the conditions for the successful implementation of this task of higher education.

Research results. The author has posed and solved in the course of the study such tasks:

- the essence of the basic concepts of research "dialogue", "interaction", "dialogic interaction" has been clarified;

- the main functions of the dialogue, the advantages of dialogical communication have been revealed;

- the conditions for students' readiness to dialogue have been revealed;

- the levels of the students' readiness for dialogic interaction have been determined;

- modern forms and methods of training managers have been justified as an important factor in achieving the necessary level of their readiness for dialogue in professional activity.

Research methods. The research uses methods of analysis and study of the modern conceptual apparatus of scientific and methodological domestic and foreign literature, periodicals on the research problem for establishing communication and dialogue problems, which are investigated by scientists; analysis, systematization, generalization, which made it possible to disclose the essence of the basic concepts of research "dialogue", "interaction", "dialogic interaction" and substantiate the importance of dialogical communication; analysis of my own pedagogical experience, which made it possible to identify the conditions for students' readiness for dialogical communication, to determine the levels of students' readiness for dialogical interaction, to justify modern forms and methods of training managers as an important factor in achieving the required level of their readiness for dialogue in future professional activity.

Discussion. It is advisable to refer to the definition of the concept of "dialogue". The term "dialogue" comes from the Greek "dialogos" - conversation, talk (dia - through, logos - word, thought) [20, p. 233]. According to the dictionary of the Ukrainian language, the dialogue is: 1) a conversation between two or more persons; 2) part of the literary work in which there is a conversation between two people; 3 ) a literary work written in the form of a conversation [19, p. 295]. From the point of view of the authors of the modern dictionary of foreign words A. Skopenko and T. Tsymbaliuk, the dialogue is: 1) a conversation, a number of statements by two or more persons on a certain topic; 2 ) in a figurative sense - a free exchange of views, negotiations [20, p. 233]. Despite several different interpretations of the concept, 
nevertheless the above definitions emphasize 1) the presence of two sides; 2) the use of language as a means of communication [19, p. 295; 20, p. 233; 21].

Today, as the field of interaction expands in various spheres of society's life, dialogue becomes an increasingly popular form of relations. In this context, the definition of dialogue presented in the Great Encyclopedic Dictionary is of interest: "Dialogue is the informational and existential interaction between the parties that communicate, through which understanding takes place. Dialogue can be interpreted as a choice by the parties of a joint course of interaction, which defines the persons "I" and "Other" [5]. M. Bakhtin regards the dialogue as the interaction of positions, opinions, personalities, voices, which goes beyond purely linguistic boundaries. He emphasizes that dialogue is a means of shaping not the personality but his or her being, not the impetus for action, but the action itself. To exist, he believes, means to communicate on a dialogical basis. Therefore, dialogue should not and cannot end [3;4]. The problem of defining the essence of the concept of "interaction" is the subject of attention of many scientists. K. Platonov, investigating personality, considers interaction as a process that takes place on the basis of mutual mental reflection [15]. V. Panferov defines interaction as a process of joint coordinated activity of people for the performance of a joint task. B. Parygin emphasizes the relationship of the parties, their mutual influence and change. According to B. Vulfov, interaction is a complex phenomenon, which involves the interaction of its subjects, the activation of their activities and is practically revealed in joint work, mutual understanding and mutual relations [23, p. 25].

Common signs of any kind of interaction, I. Zhbankova believes, are: 1) simultanity; 2) bilaterality; 3) regularity; 4) interdependence of changes in the states of its sides; 5) their internal activity [25]. The result of interaction is the formation of certain network of relationships between its participants, aimed at achieving the organization's goals, establishing it as a social unit, meeting needs of the individual. Dialogue is the interaction of two actors, which involves active participation in communication, equal rights. Dialogue is a psychological condition for the implementation of the development strategy of influence, as a result of which two persons combine a common psychological space and time extension, thus forming an emotional "being together", in which interaction in the general, monologic sense no longer exists, but the psychological unity of the subjects appears. It is such conditions for the existence of people, according to G. Kovalev, contribute to the development of their creativity and the disclosure of personality [12].

Considering the principle of dialogue as a worldview paradigm of the moral values of human orientation, N. Grinchishin draws attention to the fact that dialogue promotes tolerance in the society, understanding and patience for views and opinions that are contrary in nature, a balance in relations between people. Therefore, for the dialogue, the following are the main signs: overcoming egocentrism, affirmation of openness and closeness between communicating people, their responsibility [6; 7]. The study of the problem of dialogue acquires special significance in Ukraine, which has taken a course towards the formation of an open economy in Ukraine, its inclusion in modern civilization processes. Confirmation is the Laws of Ukraine "On Foreign Economic Activity", "On the Foreign Investment Regime", "On Special (Free) Economic Zones" and other legislative documents. In these documents, considerable attention is paid to the regulation of foreign economic relations, the elimination of conflicts, and the equal interaction of subjects of foreign economic activity [24].

Building professional activity on a dialogue basis means rejection of the authoritarian style of doing business, forming new business and friendly ties, respecting the views of other people, understanding the limits of personal freedom. Tolerance, compromise, consensus, social, political, social partnership, convinced M. Golovaty, are able to provide constructiveness in the democratic development of society $[8 ; 9]$. Formation of readiness for dialogue in professional activity in the student age is of special importance. According to scientists, during this period of life the most active development of moral and aesthetic feelings occurs, the formation and stabilization of character and, most importantly, the mastery of the full range of social functions of an adult, including civil, socio-political, vocational [1]. Taking into account the scientific ideas of L. Vygotsky, K. Platonov, S. Rubenstein, V. Slastenin, we will understand the willingness of future managers to engage in dialogical professional 
communication as a combination of motivational, cognitive, emotional, behavioral components, the interrelation of which ensures the mobilization of a system of personal qualities, knowledge and skills that allow building relations with foreign partners-representatives of other cultures positively.

In educational and qualification characteristics of the Master's degree in management of foreign economic activity it is noted that such an expert should have specialized knowledge at the level of the latest achievements, be able to analyze, organize and plan socio-economic phenomena. Specificity of the professional activity of an international manager also implies the formation of interpersonal competencies. In particular, he or she should be able to work in an international environment, maintain balanced relations with members of a team, partners, consumers, experts and other subjects of foreign economic activity [13].

It is clear that attention should be paid to questions about the methods of cognition and situations of professional activity through which it is necessary to take across students-future managers of foreign economic activity so that they could master the appropriate level of professional communication culture - a system of knowledge, skills and habits of adequate behavior in various situations of communication at the international level, experience of solving problems, methods of solving complex situations.

A. Kolesnik draws attention to the fact that dialogue is characterized by subject-subject interaction, when "...the possibility of formulating one's own point of view from the position of its own hierarchy of meanings is given to all its participants" [10, p. 63]. The training of managers must provide for a shift in the direction of greater interactivity, which expands the opportunities for interaction between participants in the learning process: between the teacher and students, students among themselves. In particular, we are talking about the use of forms of organizing classes using a training dialogue, among which the most used are discussion, debate, business game, the analysis of a specific situation. These methods provide, when discussing an important topic, competition of views, polemics, help to identify the causes of complex professional situations, lead students to a correct understanding of the various positions of people in the team [4, p. 54-55]. The most common form of education in a higher educational institution is a lecture. Lecture is more a passive way of acquiring knowledge. However, the lecture form is sometimes difficult to replace the other. New requirements for training specialists in recent years have led to an active search for ways to dialogize the lecture. In particular, there was a problem lecture, a lecture-press conference, a lecture-visualization, a lecture with planned errors. Thanks to the use of modern methodical techniques in these lectures, debatable scientific problems are clarified, the results of new scientific research are reported and summarized. Students have the opportunity not only to perceive and comprehend information, but also to master ways of finding new knowledge.

Interactive training is based on the idea that the process is as important as the result. The value of the training course is based on the process of gaining knowledge and experience, rather than simply accumulating facts. In particular, it is recognized that managerial skills, a stereotype of behavior and an adequate response to a professional situation are effectively formed in the process of joint activity of teachers and students, during which the development and exchange of skills and knowledge takes place. A participative learning style is used that encourages students to acquire knowledge and skills both from each other and from the teaching staff.

The change in the manager training model is significantly associated with the widespread use of out-of-class training. The traditional types of out-of-class work in Ukraine are study tasks related to the preparation for seminars and practical classes, writing abstracts, course and diploma papers. These activities of students, of course, are of great importance: in the process of their implementation, the knowledge gained during classroom activities is consolidated and deepened. The main activity of the teacher in organizing such classes is the presentation of information to students and monitoring the performance of out-of-class assignments in classroom activities. In our opinion, under such conditions the teacher's negative stereotypes of professional activities are formed: activity in the management of educational activities, exceeding the activity of the students' themselves; planning mainly their 
own activities, insufficient attention to the direction of student learning activities. This approach has been formed for years and therefore remains widely represented in the practice of training specialists. Modern requirements of society and the state to the responsibility of the educational institution for the provision of educational services necessitated a rethinking of the role, content and organization of extracurricular activities, and the departure from the compiled stereotypes in its organization. It takes a thoughtful and painstaking work of the teacher to choose and build educational activities. It should form students' practical readiness for future professional activity, therefore, to occur in its context.

An integral part of the professional culture of an international manager is the ability to speak and write in the official language of his or her country, using a foreign language to ensure effective professional communication with foreign partners [13]. In particular, he or she must be able to create professional documents, translate foreign professional texts, carry out bilateral translation of documents, use dictionaries, negotiate with partners in their native language or language convenient for them. Therefore, the specificity of professional training for managers of foreign economic activity is to increase attention to language training. Language culture, characterized by the correctness of speech, accuracy and the logic of constructing utterances, significantly affects the level of communicative and interactive qualities of future managers. However, the real state of teaching foreign language to future specialists for the economy in higher educational institutions of Ukraine does not always meet the requirements of today. As a rule, the number of hours to study a foreign language, provided for by the curriculum, is insufficient. Practically there are no specialized textbooks providing for various invariants of a foreign language, taking into account the preparation of students for various narrowly professional activities. Educational institutions do not have the capacity to create conditions that ensure a natural educational professional communication between students. Practically, the system of bilingual training is not used. As a result, after graduation, students do not have the necessary level of skills in oral and written speech, the inadequate stock of narrow vocational vocabulary complicates foreign-language business communication with foreign partners.

At the same time, in a circle of study subjects a foreign language has a great educational potential. The specificity of a foreign language is its interdisciplinary nature. The degree of communication with a particular cycle of subjects depends on the profile of the institution and the future profession and specialization of students. Depending on this, the foreign language can be oriented to the economic-legal, natural-scientific, humanitarian cycle, etc. This is achieved through various courses, special courses, integrative courses. Since modern language education is oriented towards the intercultural aspect, we attach special importance to the interdisciplinary relations of a foreign language with the subjects of the humanitarian cycle, primarily with the native language. Learning a foreign language deepens understanding of the native language and culture. Goethe said: "Who knows not a single foreign language, he will not know his own" [17, p. 246]. In turn, familiarization with foreign culture can be based on the culture of the native language.

Changes in society have caused the expansion of communication between people of different nationalities. The need for using a foreign language has also grown. In this regard, the priority is learning the language as a means of communication and familiarization with the spiritual heritage of the people of other countries. It is worthwhile to recall the words of Sophia Rusova: "One of the most expressive factors of social cohesion and social education is language, which is the most faithful distinguishing feature of man, his high intellectual manifestation. Language should be considered not only the verbal expression of our thoughts, our feelings, but other means of their expressions, means of mutual understanding between people..." [17, p. 51].

The development of international contacts both at the official level and at the level of informal communication enhances the integration of knowledge about the native country with the process of teaching a foreign language. Comparison of traditions, culture, life activities of people from different countries contributes to the education of future managers of foreign economic activity feelings of national dignity, their awareness of the characteristics of their people, causes interest in understanding the spiritual values of the Ukrainian people. Therefore, the Ukrainian component is of great importance 
in the content of the educational subject "Foreign Language", which we primarily associate with the definition of new approaches to the selection and organization of teaching materials, their saturation with the achievements of the national culture. This requires the invention of adequate forms of work that take into account the laws of the native pedagogy itself, founded in the pre-Christian period and developing under the influence of the events that took place in Ukraine. Therefore, it is necessary to talk about the revival of national traditions in education that have developed in the old days, and today must be an integral part of the system of national education.

Language culture is part of a common human culture. I. Pestalozzi in the work "Swan Song" noted that all means of cultural development of man must be coordinated among themselves and in order to advance man in the development of language, it is necessary to develop his heart, mind and abilities $[14$, p. 249]. They are the necessary cultural background that influences the formation of a certain point of view on the culture to which the foreign language belongs, which is being studied. Knowledge of a foreign language facilitates the adaptation of a young specialist, in particular a manager of foreign economic activity, to the conditions of professional activity. After all, his language skills, formed during the study of a foreign language, are transformed into intellectual skills, the ability to implement a communicative function, into such properties as tact and correctness in communicating in a foreign language. "Dialogic education", N. Shchurkova rightly observes, is a style of pedagogical interaction, a style of life, the organization of such a life of a pupil, when he is in constant dialogue with himself, with a picture, a book, music, another person [18, p. 93].

The organization of the learning process with the use of interactive teaching methods is of great importance, but does not exhaust all the problems of multifaceted everyday human interaction. Different forms of educational work with students are important, focused on the formation of a culture of dialogue. This work is greatly supplemented by communication with students who came to study from other countries. In particular, young people from Belarus, Azerbaijan, Turkey, China and other countries study at the departments of management of foreign economic activity of higher educational institutions of Ukraine. During joint events, communication in the dormitory and within the educational process, both Ukrainian and foreign students acquire invaluable experience of understanding and taking into account each other's needs, respect for the national traditions of other peoples.

In pedagogical literature, the question is raised about the use of potential learning opportunities through the "dialogue of cultures" model [2]. The emphasis is on strengthening the educational function of disciplines, involving students in the values of world cultures, and the dialogization of learning. The basis of pedagogical interaction, in which students' readiness to dialogue in the future professional foreign economic activity is formed, is assigned to the student as the subject of interaction, and not to the object, that is, the formation and development of subject-subject relations. Dialogue is the highest form of communication; its signs are: the existence of a goal; subject-subject nature of interaction; activity of subjects of dialogical interaction; development of mechanisms of self-regulation in subjects of dialogical interaction; the desire to achieve results on the basis of mutual understanding. Based on such signs of dialogue, the following levels of dialogic interaction can be defined: 1) low - characterized by passivity in dialogical communication and behavior, categorical statements (order, instruction, prohibition), lack of self-regulation mechanisms; 2) medium - characterized by the appearance of activity, at the same time there is an increased tone of the conversation in the event of an unwanted thought expressed by the dialogue partner, the use of negative pantone expressions, a demonstration of feelings of resentment; 3 ) high - communication of the parties on the subject-subject basis, active communication, flexible type of dialogic communication, ability to listen to a partner, use of a smile, facial expressions, gestures positive character, ability to maintain a stable positive state of health, ability to convince the interlocutor, smooth conflict moments.

E. Subbotsky draws attention to the fact that the organization of the educational process on the basis of the use of dialogical communication requires the teacher to change the traditional ideas about the style of communication on the part of both the teacher and the student [22]. In the practice of educational institutions, unfortunately, there are situations in which teachers and managers, introducing 
dialogical forms and methods of work in the educational process, in fact remain at the monologue level, making efforts in the struggle for performance indicators, the quality of knowledge. Mastering the pedagogical profession is mastering the art of dialogue, acquiring the experience of communication, perceiving the opposite position as the boundary of its further development or changes for the worse in the process of mutual adaptation. Today in pedagogical theory and practice the concepts of "cooperation", "humanization", "humane approach" were fixed. The essence of these concepts implies partnership, freedom of choice, the creation of a situation of success, positivity, dialogue on an equal footing, the activity of active parties, which leads to positive changes in the educational process and personal characteristics of interacting people. However, the realization of these ideas in the practical activities of the teaching staff is not always easy. The problem arises every time we deal with contradictions in the realities of the life of the school and the plurality of views on their solution.

Important conditions for eliminating these contradictions and effectively forming the readiness for dialogue among future managers of foreign economic activity are:

- changing the model for training such specialists in the direction of greater interactivity, introducing modern dialogue-communicative learning technologies into the teaching and upbringing process;

- change of relations between the participants in the educational process, their transformation from subject-object to subject-subject, when changes of the personality (changes in values, goals and nature of interaction, increased activity) take place;

- $\quad$ increased attention to the language training of students, the use of the potential of a foreign language as a means of intercultural, professionally-directed communication.

Conclusion. Formation in the future managers of foreign economic activity of readiness for dialogue in professional activity is a fundamental scientific problem. Dialogue, dialogic interaction, pedagogical communication are considered in our study as professional-functional categories, in this context refined for further rethinking in the process of searching for new approaches in the system of training future managers. Willingness to dialogue is one of the indicators of the future manager's formation as an individual, as a professional capable of communicating at the international level on the basis of a tolerant attitude towards the dissimilarity of views, observance of moral and ethical values.

Prospects for further research in this direction. To the priority areas of scientific and pedagogical research, we refer the problem of educational and methodological support for the dialogization of the educational process at the departments of management in a higher educational institution.

\section{References}

1. Ananiev B.G. (1972). Some Problems of Adult Psychologists / B.G. Ananjev. M.: Knowledge, 1972. - 36 p. [in Russian].

2. Bakhov I.S. (2014). Dialogue of Cultures in Multicultural Education. World Applied Sciences Journal 29 (1): 106-109, 2014. Access mode: http://www.idosi.org/wasj/wasj29(1)14/15.pdf [in English].

3. Bakhtin M.M. (1979). Aesthetics of verbal creativity / M.M. Bakhtin. M.: Art, 1979. - 424 p. [in Russian].

4. Bakhtin M.M. (1979). The problem of poetry of Dostoevsky / M.M. Bakhtin. Sov. Russia, 1979. - 318 p. [in Russian].

5. Big Encyclopedic Dictionary: Philosophy, Sociology, Religion, Esoterism, Political Economy / Ch. scientific ed. and comp. S.Yu. Solodovnikov.- Mn.: MFUP, 2002. - 1008 p. [in Russian].

6. Grinchishin N. (2008). Dialogue as the Defining Principle of Ethics by E. Levinas / Nadezhda Grinchyshyn. Access mode: [http: // www.nbuv.gov.ua/portal/natural/vpnu/ filos_psihol/2008_11/12.pdf [in Ukrainian].

7. Grinchishin N.I. (2007). Principle of dialogue as a world-view paradigm of moral value orientations and self-perfection of man / N.I. Grinchishin // Axiological aspects of the 
transformation of modern Ukrainian society: Allukr. Science-practice conf., April 27-28, 2007. - Ivano-Frankivsk, 2007. - P. 162-164. [in Ukrainian].

8. Holovatyi M. (2014). Multiculturalism as a means of nations and countries interethnic unity achievement. Economic Annals-XXI, 11-12, 15-18. [in English].

9. Holovatyi M. (2015). The state and society: The conceptual foundations and social interaction in the context of state formation and functioning. Economic Annals-XXI, 9-10, 4-8. [in English].

10. Kolesnik A.A. (2007). The meaningful dialogue in the pedagogical process / A.A. Kolesnik // Practical Psychology and Social Work. - 2007. - No. 3. P. 62-64. [in Russian].

11. Kolomensky N.L. (2000). Psychology of management in education (socio-psychological aspect): Monogr. - K.: MAUP, 2000. - 286 pp. [in Ukrainian].

12. Kovalev A.A. (1989). On the system of psychological influence / A. Kovalev // Psychology of influence (problems of theory and practice). M., Research Institute of OPP APN of the USSR, 1989, 2.5 p.l. [in Russian].

13. The branch standard of higher education of Ukraine. Educational and qualification characteristic of the master's degree in specialty 8.03060104 "Management of foreign economic activity" in the direction of preparation 030601 "Management" of the field of knowledge 0306 "Management and administration". Edition is official. Ministry of Education and Science, Youth and Sports of Ukraine, Kyiv, 2012. 26 p. [in Ukrainian].

14. Pestalozzi Johann Henry. Selected pedagogical works. In 2 t. T. 2 Compilers V.A. Rothenberg, V.M. Clarin. - Moscow: Pedagogics, 1981. - 416 p. [in Russian].

15. Platonov K.K. The system of psychology and reflection theory // Ed. G.H. Shingarov. Moscow: Nauka, 1982. - 309 p. [in Russian].

16. Rusova Sofia. Selected pedagogical works: 2 books. Kn.1 / Edited by Ye.I. Kovalenko, I.M. Pinchuk. K.: Lybid, 1997. - 269 p. [in Ukrainian].

17. Rusova Sofia. Selected pedagogical works: 2 books. - Kn.2 / Edited by E. I. Kovalenko; Notes Ye.I. Kovalenko, I.M. Pinchuk - K.: Lybid, 1997. - 320 p. [in Ukrainian].

18. Shkurkova N.E. (1994). New technologies in the educational process / N.E. Shchurkova, V.Yu. Pityukov, AP Savchenko, E.A. Osipova. M.: New School, 1994. - 112 p. [in Russian].

19. Dictionary of the Ukrainian language: [in 11 t.] / [Ed. count: I.K. Billodid (head) and others.]; Academy of Sciences of the USSR, O.O. Potebnia Institute of Linguistics - Kyiv: Naukova dumka, 1970 - 1980. T.2, 1971. [in Ukrainian].

20. Modern dictionary of foreign words: about 20 thousand words and phrases; [concluded: O.I. Skopnenko, T.V. Tsymbaliuk] - K.: Dovira, 2006. - 789 p. [in Ukrainian].

21. Soviet Encyclopedic Dictionary / Scientific Editorial Board: A.M. Prokhorov (cont.). M.: Soviet Encyclopedia, 1982. - 1600 pp. [in Russian].

22. Subbotsky E.V., Dialogue communication in education / E.V. Subbotsky, O.V. Chesnokova // Questions of psychology. 2008. No. 6. - P. 151-161 [in Russian].

23. Wulfov B.Z., Semenov V.D. (1993). School and social environment: interaction. Moscow, 1993. - 96 p. [in Russian].

24. The Law of Ukraine "On Foreign Economic Activity". The document 959-12, current, current edition, edited on January 3, 2017, basis 172419 (Bulletin of the Supreme Council of the Ukrainian SSR (VVR), 1991, No. 29, Article 377) [in Ukrainian].

25. Zhbankova I.I. (1987). The problem of interaction. - Minsk: Science and Technology, 1987. 141 p. [in Russian].

Процеси глобалізаціі, посилення міжкультурної комунікації в світовому співтоваристві визначають нові вимоги до підготовки майбутніх менеджерів зовнішньоекономічної діяльності посадових осіб, обов'язком яких є управління організацією, їі підрозділом, проведення певного напряму роботи в умовах зростання співробітництва і конкурениії в сбері економіки і бізнесу. Практика показує, що сьогодні в цій сфбері сильніше виявляються зв'язки і спілкування мін представниками різних культур як при безпосередньому спілкуванні, так і при електронній 
комунікації. Сьогодні иілі освіти менеджерів спрямовані не тільки на формування знань і вмінь у галузі і організачії проиесу управління, а й на розвиток умінь спілкуватися, чітко висловлювати власну думку, обьрунтовувати висновки щодо вирішення проблем, доносити знання, ідеї. У світлі таких вимог усе більшого значення набуває проблема формування у студентів-майбутніх менеджерів зовнішньоекономічної діяльності готовності до здійснення професійної діяльності на діалогічній основі. Метою статті єздійснити аналіз теоретико-практичних засад формування у майбутніх менеджерів готовності до діалогу в майбутній професійній діяльності і визначити умови успішної реалізації иього завдання вищої менеджмент освіти.

У статті облрунтовано місие і роль діалогічного спілкування в професійній сфері менеджерів зовнішньоекономічної діяльності, значення формування готовності до діалогу в студентському віці; здійснено аналіз понять "діалог", "взаємодія", “діалогічна взаємодія"; розглянуто умови та переваги діалогічного спілкування; визначено рівні діалогічної взаємодії в освітньому прочесі; розкрито сучасні форми і методи навчання менеджерів як важливий чинник досягнення необхідного рівня готовності майбутніх міжнародних менеджерів до діалогу; значна увага приділяється вимогам до вивчення іноземної мови - ефективного засобу підвищення комунікативних здібностей студентів і рівня їх готовності до діалогічного взаємодіі.

Ключові слова: менеджер, зовнішньоекономічна діяльність, професійна діяльність, діалог, готовність до діалогу, діалогічна взаємодія, педагогічна взаємодія, методи навчання.

\section{ДИФЕРЕНЦІАЦІЇ ЗМІСТУ НАВЧАННЯ У СТАРШІЙ ШКОЛІ ЯК ЕФЕКТИВНА УМОВА РЕАЛІЗАЦІЇ ОСОБИСТІСНО ЗОРІЄНТОВАНОЇ ПАРАДИГМИ ОСВІТИ}

\section{DIFFERENTIATION OF THE CONTENT OF EDUCATION IN SENIOR SCHOOL AS AN EFFECTIVE CONDITION OF REALIZATION OF PERSONALITY-ORIENTED PARADIGM OF EDUCATION}

у статті розкрито сутність понять “диференціація", “диференціація змісту навчання". Розкрито мету та основні завдання диференціацї змісту освіти учнівської молоді. Виокремлено та охарактеризовано форми організації диференціації змісту навчання у старшій школі.

Ключові слова: диференціація, освіта, особистісно зорієнтована парадигма, старша школа.

Епоха універсалізації освіти, енциклопедичних знань відходить у минуле. Темпи сучасного мінливого життя потребують більш раннього визначення старшокласниками сфери їх подальшої професійної підготовки. Таку можливість дає школярам диференціація змісту навчання. Практика доводить, що особистісно зорієнтована спрямованість освіти неможлива без диференційованого навчання, адже воно спрямоване як на реабілітацію відстаючих у навчанні, так і на стимулювання їхньої навчально-пізнавальної діяльності, що, у свою чергу, стає мотиваційним поштовхом у подальшому професійному самовизначенні учнів старшої школи.

У вітчизняній та зарубіжній науково-педагогічній літературі проблема диференціації змісту навчання в старшій школі досліджувалась з точки зору різних аспектів: термінологічне поле диференціації змісту навчання (С. Гончаренко, Г. Селевко, П. Сікорський); вивчення рівнів, форм і видів диференціації (О. Бугайов, П. Сікорський, Н. Ничкало, І. Унт, О. Ярошенко);

(C) Алла Загородня, 2018 